University of Nebraska - Lincoln

DigitalCommons@University of Nebraska - Lincoln

Faculty Publications: Department of Entomology

$4-17-2008$

\title{
LARVAL DESCRIPTION OF CICINDELA (DROMOCHORUS) PRUININA (CASEY) (COLEOPTERA: CARABIDAE: CICINDELINAE) WITH NOTES ON HABITAT AND ADULT BEHAVIOR
}

\author{
Stephen M. Spomer \\ University of Nebraska-Lincoln, sspomer1@unl.edu \\ Paul B. Nabity \\ University of Illinois \\ Mathew L. Brust \\ University of Nebraska-Lincoln, mbrust@csc.edu
}

Follow this and additional works at: https://digitalcommons.unl.edu/entomologyfacpub

Part of the Entomology Commons

Spomer, Stephen M.; Nabity, Paul B.; and Brust, Mathew L., "LARVAL DESCRIPTION OF CICINDELA (DROMOCHORUS) PRUININA (CASEY) (COLEOPTERA: CARABIDAE: CICINDELINAE) WITH NOTES ON HABITAT AND ADULT BEHAVIOR" (2008). Faculty Publications: Department of Entomology. 78.

https://digitalcommons.unl.edu/entomologyfacpub/78

This Article is brought to you for free and open access by the Entomology, Department of at DigitalCommons@University of Nebraska - Lincoln. It has been accepted for inclusion in Faculty Publications: Department of Entomology by an authorized administrator of DigitalCommons@University of Nebraska - Lincoln. 


\title{
Larval Description of Cicindela (Dromochorus) pruinina (Casey) (Coleoptera: Carabidae: Cicindelinae) with Notes on Habitat and Adult Behavior
}

\author{
Stephen M. Spomer $^{1}$, Paul D. Nabity ${ }^{2}$, and Mathew L. Brust ${ }^{1}$ \\ ${ }^{1}$ Department of Entomology, University of Nebraska, Lincoln, NE 68583-0816 \\ ${ }^{2}$ Department of Plant Biology, University of Illinois, Urbana, IL 61801
}

\begin{abstract}
Cicindela (Dromochorus) pruinina (Casey) is a flightless tiger beetle that was described by Casey in 1897. Since its description, it has had a diverse nomenclatural history. It occurs from Kansas and central Missouri south through Oklahoma to south Texas. Aspects of the life history are poorly known, and the larval stages have not been described. Collections of live adults from Onaga, Kansas, were transferred to a terrarium, eggs were obtained, and larvae were reared and described. Larvae were similar to other known species of Cicindela L. Notes on habitat and adult behavior were also made.
\end{abstract}

The enigmatic Cicindela pruinina (Casey) was originally described as a full species in a separate genus, Dromochorus Guérin-Méneville (Casey 1897). Since that time, it has been variously listed under Cicindela (Boyd 1982), sometimes synonymized with $C$. belfragei Sallé (Freitag 1999), or listed as either a separate species from, or subspecies of, C. belfragei (Pearson et al. 2006). Pearson et al. (2006) stated that $C$. pruinina occurs "from Kansas and central Missouri south to Nueces and Webb counties in south Texas and west into the panhandle of Texas." Also, according to Pearson et al. (2006), both "forms" (i.e., C. belfragei and C. pruinina) have been collected within a few $\mathrm{km}$ of each other in the Dallas area of Texas without showing evidence of intermediate forms. Although others may view $C$. pruinina as a morph or subspecies of $C$. belfragei, we have found that Johnson's (1992) key consistently separates species of Dromochorus, and we recognize $C$. pruinina as a full species.

Because of these different taxonomic interpretations, it is impossible to determine the actual range of $C$. pruinina without re-examining individual specimens. Cicindela pruinina may be found within holdings of $C$. belfragei, or even C. pilatei Guérin-Méneville, in museums. Many specimens of $C$. pruinina are housed in museums with the label information "Onaga KS, 10-26 July 1907, F. F. Crevecoeur," apparently the result of a population explosion and a fieldtrip collecting expedition (Ron Huber, pers. comm.).

Larval descriptions of North American tiger beetles are common in the literature, with 66 species described as of 1996 (Valenti 1996). Since 1996, only three additional North American tiger beetle larval descriptions are found in the literature: Cicindela puritana G. H. Horn (Knisley, in Leonard and Bell 1999), C. theatina Rotger (Pineda and Kondratieff 2002), and C. cursitans Le Conte (Brust et al. 2005). The life history and larval description of $C$. prunina (and other species in the subgenus Dromochorus) are unknown (Valenti 1996).

The objectives of this study were to collect $C$. pruinina in the field, study its life history, and rear and describe the larval stages. 


\section{Methods}

Potential sites near Onaga KS (Pottawatomie Co.) were visited on 5 July, 17 July, and 30 July 2005; 20 June, 29 June 2006. Searches were concentrated on roadside embankments consisting of native grasses rather than disturbed areas. Adult beetles were collected by hand. In addition, two pitfall traps were set at one site on 17 July and checked on 30 July 2005. Six live adults (two males, four females) were brought back to the laboratory in Lincoln on 5 July 2005 and caged in a two gallon, hexagonal terrarium. Local clay soil was used as a substrate, and soil was formed into a mound with a surrounding flat base. Soil was dampened with distilled water (ca. 4-6 oz.) when cracks developed. Adults and resulting larvae were fed on a mixed diet of mealworms, fruit flies, and other small insects at least once per week and maintained at an average room temperature of $72^{\circ} \mathrm{F}$. Representative individuals of the three larval stages were "fished" out with a blade of grass or mechanically removed over the next year, boiled, and preserved in $70 \% \mathrm{EtOH}$.

Larvae were examined for the following characteristics, standard for Cicindela species (see Knisley and Pearson 1984): total length (TL), width of the third abdominal segment (W3), width of pronotum (PNW), length of pronotum (PNL), width of fronto-clypeal-labral area $(\mathrm{FW})$, length of fronto-clypeal-labral area (FL), and PNL/PNW ratio.

\section{Results and Discussion}

Habitat and Adult Behavior. A total of 13 adult beetles were found at four sites within a $12 \mathrm{~km}$ radius of Onaga, all along Hwy. 16. Adults were extremely agile and fast, although flightless. Their behavior was similar to what we had observed for $C$. celeripes Le Conte, although $C$. pruinina appeared to run even faster. Adults were only seen on bare soil while scurrying from one grass clump to another. On one occasion, an adult was seen running under a rock. When the rock was lifted, the beetle had disappeared into a shallow (about $2 \mathrm{~cm}$ ) hole, where it was dug out. Adults were active when the ambient temperature was over $38^{\circ} \mathrm{C}$, and although we searched between 1600-1900 h, we did not find any beetles after $1800 \mathrm{~h}$. This is in contrast to C. belfragei, which is active until dusk (ca. 2100 $2150 \mathrm{~h}$ in late June/early July) (M. Paulsen, pers. comm.). No larval burrows were found. Pitfall traps yielded no C. pruinina. Soil at each site was silty loam or silty clay loam (USDA 1987) and strongly sloped. Grasses present included bluestems,

Andropogon spp., blue grama, Bouteloua gracilis (H. B. K.) Griffiths, and indiangrass, Sorghastrum avenaceum (Michx.) Nash.

Larval Description. Measurements given below are the means (in $\mathrm{mm}$ ) and range $(\mathrm{n}=5)$ for each instar. Abbreviations and format follow Knisley and Pearson (1984) and Brust et al. (2005).

\section{Third Instar}

(Figs. 1, 4, 5, 6)

Description. Measurements. TL 19.6 (12-24); W3 3.2 (2.1-3.7); PNW 3.6 (3.23.8); PNL 2.0 (2.0-2.2); FW 1.8 (1.8-1.9); FL 2.0 (all 2.0); PNL/PNW 0.57 (0.53$0.63)$. Color. Head and labrum dark brown/black with green reflection; pronotum dark brown/black with purple reflection; mesonotum and metanotum light brown to dark brown. Antennae dark brown with green and purple reflection. Mandibles brown, darker distally. Maxillae light brown, darker distally. Dorsal 
cephalic and pronotal setae dark brown; other body setae light brown to brown. Head. Setae numerous, ranging from long to very short. Antennal segment 1 with 9 setae, segment 2 with 8 setae, segment 3 with 3 setae, and segment 4 with 4 setae. Pronotum. 3 pairs of long setae along cephalolateral portion of disk, 3 pairs of long setae on anterior margin near midline; many ( $c a$. 50 pair) short, marginal setae. Mesonotum with $>50$ pairs of setae; metanotum with $>30$ pairs of setae. Abdomen. Sclerotized areas light brown. Third tergites with 10-12 setae. Median hooks with 1 long and 1 short, stout setae; inner hook with 1-2 thin and 3 stout setae. Fifth caudal tergites with $c a$. 40 setae, of which $c a .12-14$ are stout; epipleura with $c a .20$ setae. Ninth eusternum with 6-7 pairs of prominent setae; pygopod with 6 pairs of stout setae.

\section{Second Instar}

(Fig. 2)

Description. Measurements. TL 10.3 (0.9-12.5); W3 1.6 (1.4-1.9); PNW 2.4 (2.3-2.4); PNL 1.3 (1.3-1.4); FW 1.3 (1.2-1.4); FL 1.4 (1.3-1.4); PNL/PNW 0.57 (0.54-0.61). Color. Head and labrum dark brown with green reflection; pronotum dark brown with purple and green reflection; mesonotum and metanotum light orangish-brown to brown. Antennae dark brown with green and purple reflection. Mandibles orangish, turning dark brown distally. Maxillae yellowish orange, turning brown distally. Dorsal cephalic and pronotal setae dark brown; other body setae light brown to brown. Head. Setae numerous, ranging from long to very short. Antennal segment 1 with 4-5 setae, segment 2 with 5-6 setae, segment 3 with 3 setae, and segment 4 with 4 setae. Pronotum. 3 pairs of long setae along cephalolateral portion of disk, 3 pairs of long setae on anterior margin near midline; many ( $c a .50$ pairs) short, marginal setae. Mesonotum with $>50$ pairs of setae; metanotum with $>30$ pairs of setae. Abdomen. Sclerotized areas very light brown. Third tergites with 12-14 setae. Median hooks with one long and one medium length setae; inner hooks with 2 thin and 3 stout setae. Fifth caudal tergites with 24-28 setae, of which $c a$. 10-11 are thick; epipleura with $c a$. 12-15 setae. Ninth eusternum with $c a .8$ pairs of setae; pygopod with 8 pairs of stout setae.

\section{First Instar \\ (Fig. 3)}

Description. Measurements. TL 8.3 (5.5-9.8); W3 1.1 (0.7-1.2); PNW 1.4 (all 1.4); PNL 0.9 (0.8-0.9); FW 0.8 (0.8-0.9); FL 0.8 (0.7-0.9); PNL/PNW 0.63 $(0.57-0.70)$. Color. Head and labrum dark brown with green reflection; pronotum light brown to dark brown with green and purple reflection. Mesonotum and metanotum brown. Antennae brown. Mandibles orangish, turning dark brown distally. Maxillae yellowish-orange, turning brownish distally. Dorsal cephalic and pronotal setae light brown to dark brown; other body setae light brown to brown. Head. Ca. 12 pairs of long setae. Antennal segment 1 with 1 seta, segment 2 with 2 setae, segment 3 with 2 setae, and segment 4 with 4 setae. Pronotum. 3 pairs of long setae along cephalolateral portion of disk, 1 pair of long setae on anterior margin near midline. $\mathrm{Ca} .12$ pairs of shorter, marginal setae. Mesonotum with $c a$. 20 pairs of setae; metanotum with $c a$. 10 pairs. Abdomen. Sclerotized areas indistinct. Third tergites with 4 setae. Median hooks with one stout seta; inner hooks with 2 stout setae. Fifth caudal tergites with 3 long setae, epipleura 

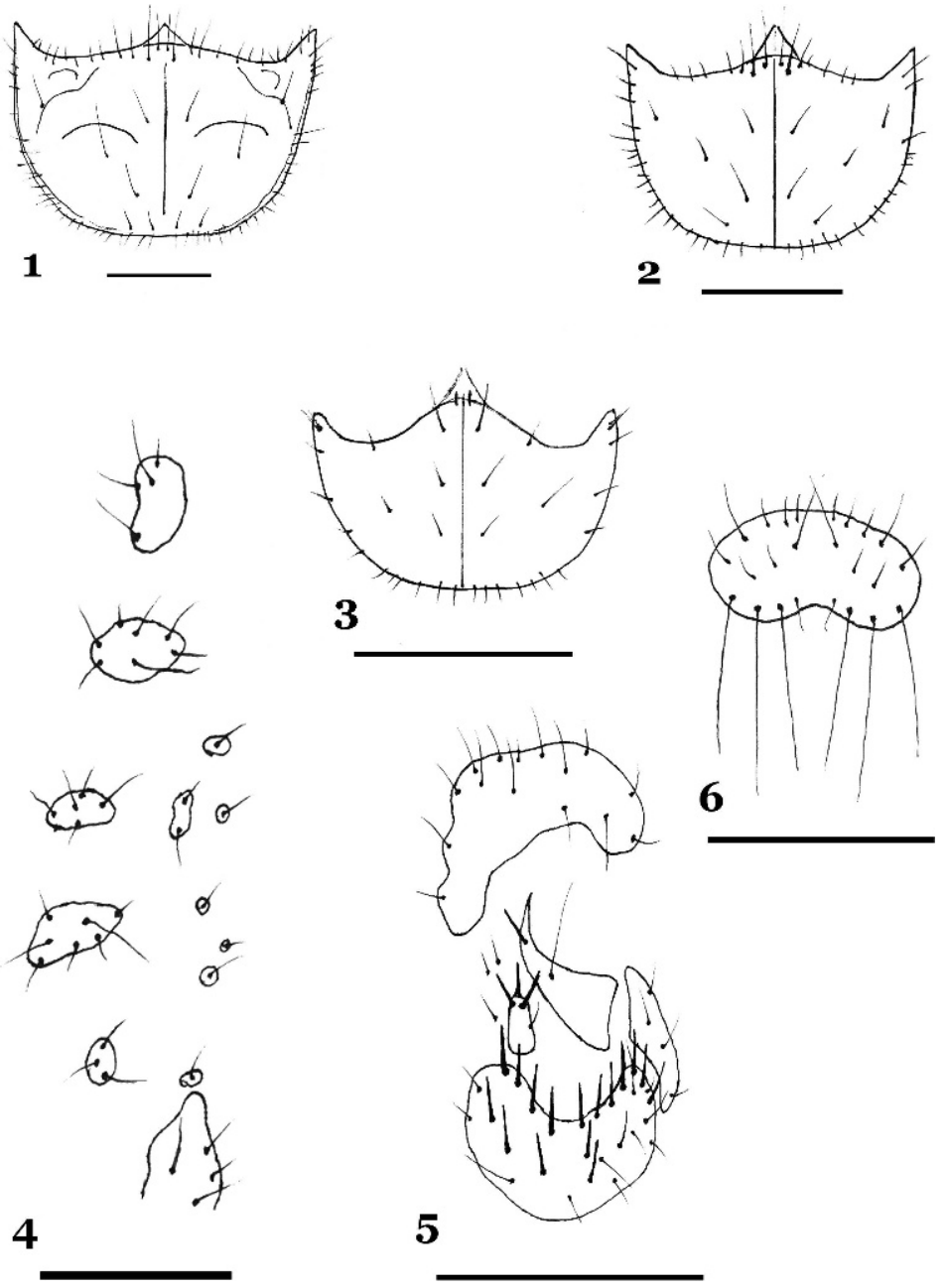

4

Figs. 1-6. Cicindela pruinina. 1) third instar, pronotum; 2) second instar, pronotum; 3) first instar, pronotum; 4) third instar, third abdominal segment, lateral aspect; 5) third instar, fifth abdominal segment, dorsal aspect; 6) third instar, ninth eusternum, ventral aspect. Scale bars equal $1.0 \mathrm{~mm}$.

with 3-4 stout setae. Ninth eusternum with $c a$. 8 pairs of setae; pygopod with 3 pairs of stout setae and a few thin setae.

Life History. Captive adults were given a choice of mounded (sloped) or flat clay soil on which to oviposit in the terrarium. Larval burrows began to appear about 2-3 weeks after adults were introduced. About $75 \%$ of the burrows appeared on the sloped clay, while $25 \%$ were on the flat soil. Nearly 50 larvae were obtained from eggs laid by the captive adults.

C. pruinina probably has a two year life cycle. After one year, most larvae were 2nd instar, with a few 1 st instars and 3rd instars. After 18 months, nearly half of 
the larvae were 3rd instars. Larvae will continue to be monitored for the remainder of their life.

Observations of the larval morphology of $C$. pruinina indicate it is remarkably similar to most other species of Cicindela, even though adults are quite distinct morphologically. From this study alone, therefore, it is inconclusive whether Dromochorus is sufficiently distinct from Cicindela to elevate it from subgeneric to generic rank. In addition, future studies may want to focus on $C$. belfragei and compare it to $C$. pruinina. Knowledge gained from this study will allow a better understanding of the relationship between C. pruinina and the other Dromochorus species.

\section{Acknowledgments}

We wish to thank Brett C. Ratcliffe, William J. Allgeier, and C. Barry Knisley for their reviews and suggestions.

\section{Literature Cited}

Boyd, H. P., and Associates. 1982. Checklist of Cicindelidae: the tiger beetles. Plexus Publishing, Inc., Marlton, NJ. 31 pp.

Brust, M. L., W. W. Hoback, and C. B. Knisley. 2005. Biology, habitat preference, and larval description of Cicindela cursitans Le Conte (Coleoptera: Carabidae: Cicindelinae). Coleopterists' Bulletin 59(3):379-390.

Casey, T. L. 1897. Coleopterological notices VII. Annals of the New York Academy of Sciences 9:285-684.

Freitag, R. 1999. Catalogue of the tiger beetles of Canada and the United States. NRC Research Press, Ottawa, Ontario, Canada. 195 pp.

Johnson, W. N. 1991 (1992). A new species of Dromochorus from southern Texas (Coleoptera: Cicindelidae). Cicindela 23(2-3):49-54.

Knisley, C. B., and D. L. Pearson. 1984. Biosystematics of larval tiger beetles of the Sulphur Springs Valley, Arizona. Descriptions of species and a review of larval characters for Cicindela (Coleoptera: Cicindelidae). Transactions of the American Entomological Society 110(4):465-551.

Leonard, J. G., and R. T. Bell. 1999. Northeastern tiger beetles: a field guide to tiger beetles of New England and Eastern Canada. CRC Press LLC, Boca Raton, FL. 176 pp.

Pearson, D. L., C. B. Knisley, and C. J. Kazilek. 2006. A field guide to the tiger beetles of the United States and Canada: identification, natural history, and distribution of the Cicindelidae. Oxford University Press, Inc., New York, New York. 227 pp.

Pineda, P. M., and B. C. Kondratieff. 2002. The larvae of Cicindela theatina (Coleoptera: Cicindelidae), a regional North American sand dune endemic. Entomological News 113:163-172.

USDA Soil Conservation Service. 1987. Soil survey of Pottawattomie County, Kansas. U.S. Government Printing Office, Washington, D.C. 153 pp.

Valenti, M. A. 1996. Synopsis of reported larval descriptions of tiger beetles (Coleoptera: Cicindelidae) from North America north of Mexico. Cicindela 28(3-4):45-52.

(Received 21 March 2007; accepted 1 December 2007. Publication date: 4 April 2008.) 